Михаило М. Шћепановић Универзитет у Београду

Филолошки факултет
$811.163 .41 ' 272(497.16)$

https://doi.org/10.18485/ai_cirilica.2017.ch8

\title{
СРПСКИ ЈЕЗИК КАО ЦРНОГОРСКИ
}

(На примјеру накарадне израде Рјечника

Црноі̄орскої наровноі̄ и књижевноі језика

и српски говорни простор данас)

У раду се разматрају актуелне тенденције у развоју српске дијалекатске лексикографије, даје осврт на методолошке поставке код израде дијалекатских речника (од одабира одреднице и сагледавања њеног суодноса са суседним говорима и говорним типовима на једној, и стањем у стандардном језику на другој страни). Рад доноси и библиографију о досадашњим лексикографским резултатима из ове области, као и поглед на методолошке проблеме који прате ову врсту лингвистичких истраживања. На основу таквог предлошка и сагледавања целокупног српског говорног простора и актуелних лингвополитичких прекрајања тог простора, те преименовања српског језика, анализира се као последица и појава првог тома Рјечника ирноі̄орскої народної и книжевної језика, као аматерског приступа лексикографској науци.

Кључне речи: дијалектолошка лексикографија, лексикографски поступак, дијалекатски речник, дијалексема, урбани дијалекат, прекрајање језика, српски језици.

\section{1. Непоменути црногорски Рјечник}

у светлу српске дијалектолошке лексикографије

Вуков Рјечник из 1818. године, представља, како је више пута примећено, темељ, не само српске дијалекатске лекси- 
кографије, већ и српске модерне лексикографије. У основи Вуковог првог издања је његов Тршићки говор, па није ни чудо што га је Павле Ивић (1991:69) окарактерисао као „речник говора једног човека“, јер како каже исти аутор: „Други речници садрже речи из различитих извора, које су употребљавали разни људи, често у разним временима и разним крајевима, дакле речи које не коегзистирају у једном језичком систему или се налазе у систему књижевног језика механички помешане, помало као случајни пролазници на тротоару велеграда. Насупрот томе, лексика органски развијеног индивидуалног говора сачињава кохерентан систем, она обухвата онолико речи колико је потребно да се покрију значења која постоје у амбијенту и психичком свету њеног носиоца. Значењска поља тих речи су по правилу јасно разграничена, а тамо где се јавља синонимија, она није плод случајног сусрета двеју речи из различитих извора, већ има дубље узроке. Све је пропуштено кроз јединствено језичко осећање, што постаје још већи квалитет онда када је упитању појединац обдарен изванредним језичким осећањем, а уз то човек из народа, способан да међу језичким елементима који су му познати, издвоји оне истинске народне, понете из родитељског дома“ (Ивић 1991: 69-70). Но, без обзира на чињеницу да је Вуков Рјечник из 1818. имао немерљив значај, не само за српску лексикографију, већ и за српску културу уопште ${ }^{1}$, до појаве првенца дијалекатске лексикографије Срби ће чекати више од једног века. Српска дијалекатска лексикографија јавља се, како примећује Д. Ћупић (2000: 703), иза резултата испитивања народних говора, „јер је било значајније описати говоре као цјелине, него давати

Лексичко благо било ког говорног типа српског језика, као и лексичко благо језика уопште, „када се пажљиво анализира, даје бројне информације о етникуму који се њиме служи, културним навикама тих људи, делатностима којим се они баве, историјским контактима са другим народима. На тај начин дијалекатски речник постаје извор информација за друге друштвене науке“ (Илић 2005: 23). 
и њихову комплетнију лексику“. Уз ово треба додати да је почетак модерне српске дијалектологије везан за освит двадесетог века и појаву познате Белићеве монографије у првој књизи СДЗб (1905), а елементе дијалекатске лексикографије налазимо и у регистру те књиге, тј. Белићевих Дијалекай исйочне и јужне Србије. Ту је додат богат регистар, од око 6.000 ријечи, истина, неакцентованих и датих само у једном облику. Белићев пример, додавања народне лексике уз монографије о појединим српским говорима следили су, мање-више успешно, и неки каснији српски дијалектолози.

Овим освртом на услове настанка српске дијалекатске лексикографије, није могуће заобићи невесели историјски контекст у коме се нашао српски народ у првој половини двадесетог века (Балкански ратови и Први светски рат), што је уназадило његов укупни духовни живот, а тиме и све научне дисциплине које су тада излазиле из повоја.

2.

Дијалекатским речником, по мишљењу Драгољуба Петровића (1990: 7), може се сматрати сваки речник који је ослоњен на језичке реалности одређеног ареала народних говора. Према синтетичким презентацијама новијих истраживача (Илић 2005: 19) показано је да, нпр. и америчка лингвистичка терминологија дијалекат тумачи као било коју језичку различитост у систему, из чега би следило да и жаргон појединих струка, арго, сленг, па и тајни занатски језици, припадају корпусу дијалекатске лексике. То се може једино прихватити уз услов да је лексички корпус дате «специјалне» лексике и прецизно просторно омеђен, и да се, он као такав, улива у корпус урбане лексике датог језика одређеног говорног типа.

Пошто је поникао из окриља дескриптивне дијалектологије, сваки дијалекатски речник, међу осталим врстама 
речника 2 , означен је њеним методолошким обележјима, с тим да је у свом основном својству уједно и синхронијски, јер је по Згустином схватању (1991: 193) и сврха «синхронијских речника да се баве лексичком залихом неког језика на неком ступњу његовог развоја». Из оваквог схватања произилази и тврдња да, према методологији обраде, сваки дијалекатски речник може бити: 1) општи (нека врста репрезентативног тезауруса за прецизно омеђену географску област); 2) диференцијални - a) у односу на други говор, говорни тип или суседни дијалекат; и б) у односу на књижевни (стандардни језик). Прво схватање у својим теоријским радовима прихвата, пре свих Драгољуб Петровић (1982: 199), који то илустративно поткрепљује тврдњом: 'Речи ойаи, мајка,

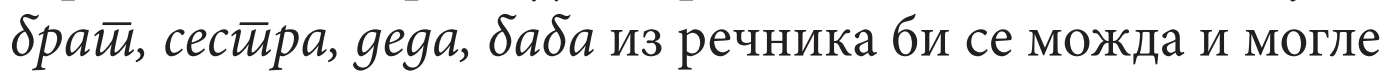
искључити, јер се очекује да ће степен њихове идентификације бити практично занемарљив. Против њиховог искључивања, међутим, говоре два битна факта: (1) све те речи припадају једном терминолошком језгру - терминологији сродства и (2) њихова деривација може бити веома разноврсна и почесто чак и знатно диференцирана". Исти аутор на другом месту подвлачи да је 'свака реч дијалекатска када се среће као интегралан елеменат одређеног дијалекатског лексичког система без обзира на то какав је њен однос према стандардном језику" (Петровић 1990: 7). Овакав приступ можемо прихватити једино ако прихватимо предуслов да је примена структуралног метода у обради дијалекатске лексике једино могућ и оправдан поступак, уз претпоставку да дати језик нема општег речника, а то свакако са српским језиком није случај ${ }^{3 !}$

2 О врстама речника в. шире у Ћорић 2008: 212.

3 Истина, отежано је повлачење прецизне границе између стандарднојезичке и дијалекатске лексике, пре свега због нејасно искристалисане и недовољно стабилне граматичке 
Од петнаестак дијалекатских речника - како наводи Ћупић (2000: 704) - колико смо их нашли у српској дијалекатској лексикографији, укључујући и онај бачких Буњеваца и два речника романизама из Боке Которске, пола њих су радили лингвисти, а половину - људи различитих нелингвистичких струка. Регистре, односно збирке ријечи уз монографије, радили су лингвисти, а збирке које су рађене за РСАНУ давали су људи најразличитијих професија.

Ниво обраде речника је различит. Они које су радили лингвисти имају комплетнију граматичку обраду и богатије су опримерени. Иначе, као што је познато, у обради дијалекатске лексике у речницима постоје и различити поступци и различита схватања. Највише обрађивача дају само ону лексику која се сматра диференцијалном у односу на Вуков Рјечник из 1818, и касније речнике, или у односу на књижевни језик. „Међутим, ниједан речник није обрађен као строго диференцијалан, јер се, истина у селективном виду, уноси и општа лексика, најчешће када је у питању неко специфично, локално значење, или дијалекатски лик лексеме“ (Ћупић 2000: 704).

Ту је методологију успоставио још Гл. Елезовић у првенцу наше дијалекатске лексикографије, послије Вуковог Рјечника, у Речнику косовско-метиохијскоі gијалекй $а$, објављеном у два тома у СДЗб 1932. и 1935. године (СДЗб IV, 1932, и VI, 1935). Обима од неких 15-так хиљада ријечи, овај речник је обухватио апелативску лексику, дијелом и ономастичку. Аутор се дјелимично служио и писаним изворима (што се касније све ређе чини), тј.

(семантичке и морфолошко-творбене) норме, мада општи услови, уз постављање јасних критерија, омогућавају израду дијалекатског диференцијалног речника. Тај поступак је, свакако, вишеструко тежи, али није и неостварив, јер није занемарљива традиција српске дијалекатске лексикографије од једног и по века. 


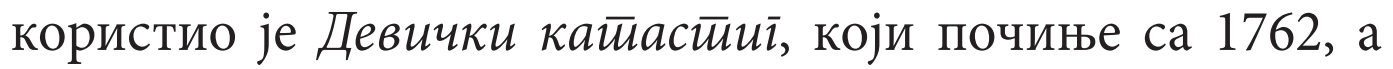
завршава се са 1789. годином. У предговору аутор наводи да је речник обухватио неколико категорија ријечи: „а) све речи које нисам нашао ни у Вуковом речнику ни у речницима Југословенске академије и Броз-Ивековића; б) оних речи којих нема у Вука, иако их има у речнику Југословенске академије или у речнику Броз-Ивековића; в) оне речи којих има у сва три поменута речника, али се по чему било разликују по облику или по значењу укупном или делимице; г) најзад, унесене су и ређе речи за које нема потврде у другим речницима осим у Вука (...) Известан број речи турског порекла унете су и кад се ни по чему не разликују од истих речи код Вука (...)“ (Елезовић 1932: Х)

Лексички фонд у Елезовићевом речнику се може везати за период од краја 19. и почетка 20. вијека, пошто је аутор у њега уносио податке које је добијао од старијих и најстаријих информатора, какав је и иначе обичај у испитивању дијалеката, као и нешто лексике из 18.

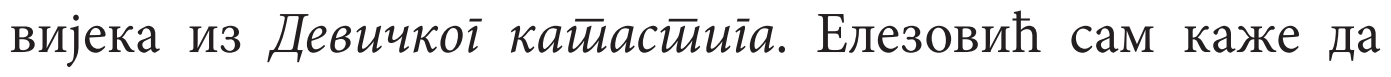
се стиче утисак да има много турских ријечи, односно ријечи оријенталног поријекла, али овдашња лексика према ријечима овога поријекла, каже, у истом је односу као у већини српских говора (Предговор, стр. 10)

Речник је поново штампан у Приштини 1998. године. Толико о првенцу српске дијалекатске лексикографије. „У вези са дијалекатским речником - како наводи Ћупић - поставља се више питања, а међу њима: да ли се ради о речнику једног говора диференцијално у односу на друге говоре, односно на лексику књижевног језика, са тзв. семантичким дијалектизмима; да ли је такво дјело скуп фонолошко-фонетских, лексичких и других особености говора и њихов однос према неком другом идиому; је ли то речник диференцијалан у односу на Вуков лексикон, или је то пак сва лексика која живи у једном говору, без обзира на углове посматрања дијалекатске слике; или 
је то, можда, скуп руралних терминологија без лексике која обухвата најопштије и посебно апстрактне појмове, итд. По нашем схватању, дијалекатско лексикографско дјело јесте скуп свих тих елемената, али истовремено и било који од наведених сегмената, зависно од задатака које аутор таквом дјелу поставља“ (Ћупић 2000: 706).

Другим ријечима, Ћупић сматра да дијалекатски речник не може бити довољно функционално дјело уколико не садржи сву лексику која се односи на живот у одређеној средини. А колико ће дати и друге лексике, она која је у говору позната али не припада само њему, то је питање концепције лексикографског дјела и његовог циља. То значи да дијалекатски речник треба првенствено да буде диференцијалан у односу на језик којему говор припада, нарочито ако се ради о посебним значењима у говору чија се лексика обрађује. Такав речник не би био довољно функционалан уколико не би обрађивао и ономастичку грађу (макар топониме, а антропониме - макар по избору).

Овдје су нам занимљиви ови ставови, јер је ријеч о коаутору Речника іовора Заіарача, једном од најкомплетније урађених речника са простора говора Старе Црне Горе. Наиме, објашњавајући због чега говор Загарача није примио говорне особине Бјелопавлића, Ћупић објашњава „условима живота током средњег века, када су се дешавале крупне језичке промјене и у српском језику као цјелини и у његовим дијалектима“... и да „речник садржи око 10.000 ријечи и макар три пута толико значења, што значи да може успјешно да представи дијалекатску лексику загарачког говора, али и говор у цјелини“"(Речник говора Загарача: IX, XVII).

Пошто су обрађивачи (ако их је и било!) Рјечника ирноїорскої наровної и кюижевноі језика (I, $A-B)$, обилато користили Ћупићев Речник, онда је очито да ништа нису научили из његовог предговора, као и из раније објављених радова, што ћемо потврдити у редовима који слиједе. 
3. Црногорски Рјечник у контексту Сарајевске gекларације о зајеgничком језику, а против српског народа и његовог језика

После пола века од потписивања Декларације о хрватском књижевном језику, којом је јавно отпочело разбијање српскохрватског језичког заједништва, Србима је уз Рјечник Црноїорскоі наровноі и кюижевног̄ језика потурена под нос још једна „шарена лажа“ рачија о повратку зајеgничкоїа нам, али безименоі језика, лепо упакована у хаље „шарене лаже“, којој је машницу притегла директорка Центра за културну деконтаминацију, звана Борка Павићевић, уз велику свиту разнородних сватова са ширег штокавског, тј. српског говорног простора. Српски медији су доста озбиљно пропратили овај Боркин наум, поднесен у латиничком једнолистку на загребачкој варијанти српскога језика, о чему сведоче препознатљиве варијантно обојене лексеме. Да су се извршитељи оваквога лукавог наума, добро ослоњени на неумитне лингвоисторијске чињенице, досјетили да заједнички језик, што је истина, Срба, Хрвата, Бошњака и Црногораца, именују, што је опет истина - као срӣски језик, онда би уштедели доста новинског простора као и времена за озбиљније србистичке, (а може и србокроатистичке) теме. Но, требало је оправдати уложене паре, макар и у корист сопствене штете, прецизније, штете српског језика и његових говорника.

Кад рекох лукави наум онда сам дужан да ближе објасним ову синтагму. Наиме, у Декларацији стоји да се потписници залажу да се избегну непотребна превођења, да се заустави штетна пракса раздвајања језика, траже уважавање језичке разноврсности и „prožimanje različitih

4 Овај одељак представља синтезу текста из: М.Шћепановић 2017: 56-57. 
oblika i izričaja zajedničkog jezika na sveopću korist svih njegovih govornika“. Све је то у реду, само остаје питање шта Срби имају с тим? Да нису српски лингвисти поцепали заједнички језик? И то су преумили састављачи „Декларације!! А онда централно место у овом списанију разјашњава Ранко Бугарски, један од потписника: „Не

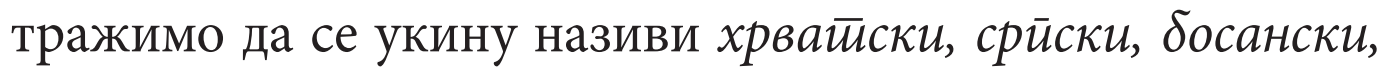
uрноїорски, него инсистирамо да су они равноправни и да заједно чине једну лингвистичку цјелину у ширем смислу која је раслојена на варијанте“" (Политика, 30.03.2017: 13). Другим речима, срйски језик је варијанйа срйскої језика, а све то изазива нове последице! Нимало наивне.

Занимљиво је да су Хрвати овај документ дочекали с ниподаштавањем, што не чуди ако се зна да свако претресање по историји њиховог књижевног језика мора кренути од српскохрватског језичког заједништва и фалсификаторских потеза, који су довели до садашње хрватске лингвистичке стварности. Прво су се одрекли сопственог чакавског дијалекта, прешли на штокавицу, и како је Гај, још 1852. записао йриіртлили срӣски језик, а под српскохрватским заједништвом стабилизовали књижевнојезички израз, а потом пре пола века измислили закон по коме сваки народ има право да може свој језик назвати по националном имену. Ту измишљотину је разобличио Бернард Грошел (2003: 135-196), немачки слависта, показујући да такво правило не познаје ниједан закон светских и европских друштвених организација. Данас хрватски премијер Андреј Пленковић поносно изјављује да је хрватски, језик хрватске државе, и што је још битније да је хрватски један од званичних језика ЕУ. У исто време, српски лингвиста из Хрватске, Милорад Пуповац пребројава нападе на Србе у Хрватској, па их је 2016. нанизао до броја 331! Еуройски и демократски. А хрватски премијер и даље финанцира у Загребу веома значајне граматике српског језика, мада под вештачким именом, 
што је само показатељ да сваки језик, ако је језик, а то је срйски језик - мора бити ослоњен на сопствене историјске темеље.

Доста је потписника ове Декларације са босанскохерцеговачког и црногорског говорног простора, што је опет разумљиво јер су они изродили лингвистичку недоношчад, па им је потребно доста дадиља да се недоношче „подњиви“. Грамайику босанскоі језика је лингвистички нокаутирао први босански лингвиста Мидхат Риђановић обимном студијом TOTALNI PROMAŠAJ (Prikaz Gramatike bosanskog jezika Dž. Jahića, S. Halilovića i I. Palića, Drugo izdanje, Sarajevo 2003, 179 str.), децидирано показујући да је немогуће „утерати брод у каменицу“. Сви остали покушаји се своде на фалсификовање, како историјских, тако и лингвистичких чињеница. Стога препоручујем проф. Милошу Ковачевићу да уместо полемике с господином Џенисом Шаћировићем, када му оде у госте, у Бошњачку академију наука или у Матицу Бошњака Санџака, понесе као „прави кавалир“ по неколико примерака студије Мидхата Риђановића и тако обогати њихове библиотеке о непостојању босанског језика.

У афоризму Милена Миливојевића Huје ирноі̄op-

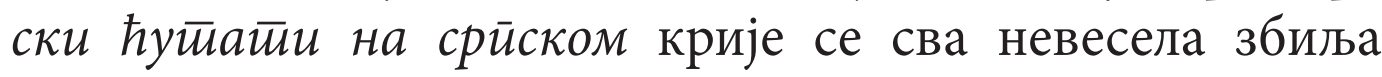
статуса црногорског језика. Пошто се тамо шачица власти приљежних лингвиста поинатила, па не знадоше „начињети“ граматику црногорског језика, онда је власт актуелна нашла спасоносно решење и ангажовала двојицу знаменитих хрватских лингвиста Прањковића и Силића уз обавезно дописивање и познатог домаћег стручњака Аднана Чиргића. Тако се љета господњег 2010. појави на подловћенској „арији“ у цигла-црвено измолованим корицама Gramatika crnogorskoga jezika на издавачким леђима Ministarstva prosvjete i nauke Crne Gore. Књигу је добро критички „протресао“ проф. Ковачевић показујући алфабетско правило да наука не почива 
на измишљотинама и компромисима, него на научним чињеницама, а научна чињеница је имуна на политичке диктате. Тако и ово лингвистилистичко (не)дело може

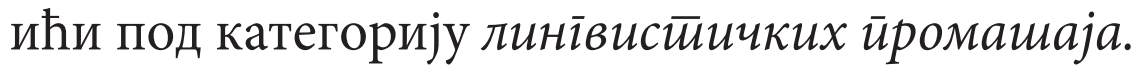

Када се и овако овлаш сагледа историјат новонасталих прирепака српског језика, онда је најновија Декларација више него штетна, како за српски језик тако и за српски народ. То је планирана завршна фаза сламања српског језика и збијања његовог говорног и културног простора. Рекао бих хеклераиија српског језика и Срба. И то најмање из три разлога:

1. Декларацијом треба забетонирати постојеће стање и тако српски језик изједначити са постојећим назови-језицима који још нису стекли пунолетство, а тиме српском језику подсећи лингвоисторијске корене, из чега следи -

2. Треба назови-језике сместити у постојеће границе и тако српски језик свести на србијански, што би омогућило његово даље територијално, социјално и свако друго растакање, из чега следи -

3. Укидање Републике Српске, завођење босанског језика у Босни, баш према давној Калајевој замисли. Црногорска збиља је више него опомињућа. Латинизација и изгон српског језика са простора Црне Горе само говори о чињеници да је ова Декларација смишљено напакована да Србе ван Србије чекају невесели дани. Видимо њихов положај у данашњој демократској Хрватској. У Црној Гори су грађани деветог реда. Актуелној црногорској власти је успело оно што није успело аустроугарским и италијанским окупаторима.

Tо је довољно разлога да српски културни и јавни радници добро промисле шта и у име кога потписују, а да лингвистичке аналфабете промијене занимање.

$* * *$

Истина, црногорско лексикографско недоношче не сачека да га окураже gекларайори (Рајка, Балша и 
др.), него „пиону“ прије но га уселише у књижарске излоге. Тако је обршила, колико се сјећам и Gramatika crnogorskog jezika Vojislava Nikčevića - a то je Рјечник ирноїорскоі̄ народної и книжевноі̄ језика (Црногорска академија наука и умјетности, Институт за језик и књижевност „Петар II Петровић Његош“, Рјечници, Књига 8/I) 5 . Рјечник је угледао свитање 2016. године, мада му је убрзо смркло и повучен је из јавне употребе. Тако да се морамо приупитати колико је сврхе и обазирати се на неозбиљне књиге још неозбиљнијих аутора, али с обзиром на чињеницу да ју је изњедрила највећа научна установа Црне Горе, и да се њоме хтјела заокружити језичка црногоризација овог дијела српског говорног простора, наводи нас на помисао да није бескорисно незнавеницима указати na „greške u koracima“!

У редакторском предговору смо обавијештени да се „у трећој фази приступило издвајању основних облика одредничких ријечи из корпуса различитих облика ријечи, што је резултирало израдом и објављивањем

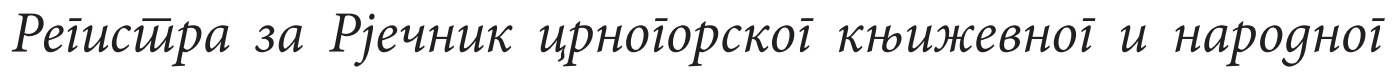
језика, који допуњен садржи око 100000 ријечи“. Ако знамо да прилози (речници и лексикони уз дијалекатске монографије) из српских народних говора са простора Црне Горе прелазе и преко 200000 одредница и најмање три пута толико значења, и да су то научни подухвати, онда нам је и без образложења јасна научна методологија ових лексикографских мобеника. Већ на првој страници Преgїовора читамо да је „Црногорска академија наука и умјетности обезбиједила најсавременију опрему за скенирање текстова, а намјенски креирани и посебно купљени софтвери, као и специјални рачунарски програми, омогућили су ефикасно формирање предметног корпуса (...)“ (стр. Х). Слава Академији! Ипак, у заврш-

5 Подробније у : Ковачевић и Шћепановић 2002. 
ним редовима Преgіовора не може се заобићи наглашавање „да постоји могућност да нека ријеч није добила статус одредничке ријечи у Рјечнику, што је посљедица некомплетности Изворника или ӣрисуйне ірешке у оgīoварајућем рачунарском йроіраму (курзив М.Ш.). Дакле, окривљујемо најсавременију оирему и сиецијалне рачунарске ирроіраме за остварење потпуног лексикографског промашаја. Колико год покушавали да озбиљно освијетлимо овај лексикографски покушај, морамо признати да и из Преgїовора исклијава макар зрно искрености. Лако је закључити да су овом (не)дјелу за ослонац послужили озбиљни дијалекатски речници са простора Црне Горе (в. Библиографију), што посредно осликава наслов (Рјечник нароgноі̄ и книжевної j.), или да се бар разликује од српског, као да немају готове дијалекатске речнике са скоро целокупног српског говорног простора Црне Горе, или је пак хипотеза редактора да народне говоре Црне Горе обогаћује лексика књижевног језика, па ће тако црногорске бабе прије научити ријечи (нпр. блоі, блоіер, блоїерка, и. сл. s.v.). Биће по сриједи да су постојећи дијалекатски речници били добра „подумента“ за копирање (скенирање), тј. крађу, а онда остаје само да се мало „промијеша“ семантичка дефиниција, пригрне нормативна акцентуација извучена из нормативних речника српског језика и „ето љепоте“! Ипак нису се могли покрасти сви примјери, па су одреднице остале голуждраво опримјерене или без илустратора, па остаје да се обрађивачима и редакторима вјерује на ријеч. Друкчије речено, што је преписано, преписано је неуко, а што је написано, то је незнавено! Ако на примјер поредимо (мада је то илузорно) одредницу $\boldsymbol{a}$ РСАНУ, којој је посвећено шест речничких стубаца, у РјЦАНУ обрађена на пола ступца у 43 ретка, али да се зна да црногорски језик има $a$-класу,

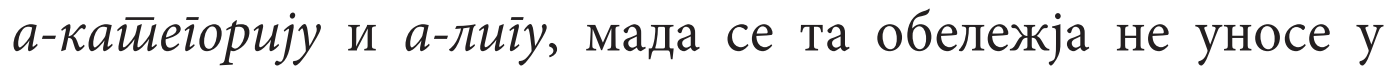
озбиљне речнике (в. Прилоге 2, 3). 
Овдје је значајно, иако оштрије интонирано, навести и мишљење Драгољуба Петровића (2017: 20-21), највећег живог српског дијалектолога, који је у осврту овако окарактерисао Рјечник ирноі̄орскоі нароgної и књижевноі̄ језика ЦАНУ: „Црногорска академија наука и умјетности је друштво стараца, геронтолошки центар - такорећи (једна моја баба рекла би „герељашки“), и они ништа боље нијесу ни могли чинити. Осим да краду и лажу. А да их питаш зашто то раде - не би ти умјели одговорити ни за лупештине ни за лажавине. У томе друштву, може бити, има покоји занатлија, али међу њима нема ни интелектуалаца који о проблемима умију мислити нити лингвиста који би им рекли како се речници припремају и како су знања за њихову припрему неопходна.“

Физиономију тога речника одредио је један стари општински секретар и није ни чудно што је то учинио тако сакато и незнавено (на основу чињенице да је тај језик унио у Устав Црне Горе, он мисли да је стекао тапију на то да са тим језиком и даље чини што му се кад допадне). Такав речник какав је он потписао први пут је замишљен прије 130 година, његов први том (досад их је објављено двадесетак, а можда ће их бити још толико) појавио се 70 година касније и за њега ће убрзо бити речено да је то највећи светски лексикографски подухват... И то су црногорски лингвистички мајстори преузели и потписали као Рјечник ирноїорскоі̄ нароgної и књижевної језика и тамо надробили сваки аветлук...!

Тако се десило да се ЦАНУ, на челу с оним општинским секретаром и уз помоћ акад. Бранислава Остојића (који је томе речнику „одредио лингвистичке мјере“ документом 02-691/1 од 27. априла 2011)6, упустила у

6 Колико ми је познато, академик Остојић се није јавио на ову Петровићеву прозивку. Истина, имена академика Бранислава Остојића нема у импресуму Рјечника ирноїорскоі нароgноі̄ и књижевног̄ језика, ни међу Редакторима, ни у Савјету, ни 
лексикографску крађу пошто је, прије тога, језик под лажљивим именом уписала у црногорски устав и на велики вјетар дигла - велико застиђе. И то учинила не знајући ни како се то чини ни зашто се то чини управо тако а не некако друкчије и, да им не буде много, макар мало паметније.

Ово последње, међутим, друкчије није ни могло испасти с обзиром на то ко је томе речнику постављао темеље и с којом је памећу то учињено: ако су Руси одмах схватили да се по истој мустри не могу радити речници књижевног / стандардног језика и дијалекатски речници, ако Срби ... истрајавају већ деценијама, ЦАНУ је имала образац који је морала избјећи (1. „рјечник треба значајно попунити ријечима из народног језика“), али ако

међу Консултантима, тако да остаје отворено питање откуд име и потпис академика Остојића на документу који помиње Драгољуб Петровић. Радећи на овом тексту, до руку ми је случајно дошао спорни документ насловљен О Рјечнику ирноіорскої наровної и књижевної језика. Изнад тога текста стоји име академика Остојића, а на крају пете стране и својеручан потпис. Текст је конципиран и подељен у поднаслове: Формирағе лексикоїрафске іррађе за Рјечник ЦАНУ; Прийреем (sic!) за раg на Рјечнику ЦАНУ. Прикуйлағье ірађе, затим следе наслови Лексикоірафска обраgа у Рјечнику ЦАНУ; Израgа лексикоїрафских уйуйстиава за Рјечник ЦАНУ; Основна конщеичијска начела и на крају Заврине найомене, где се наводи „У Институту Петар II Петровић Његош радили би се - Рјечнищи ирноіорских народних іовора (рук. Б. Остојић), Рјечници ирноіорске ономасииике (рук. Н. Вуковић), Рјечник ирноі̄орскоі̄ народної и књижевноі̄ језика (3. Радуловић)“ (страна 5). На последњој страни наведеног документа стоји латиницом Predlog članova programskog savjeta међу којима стоји и Остојићево име и његов потпис на дну овог документа. Шта се десило између 27.04.2011. до 2016. године, када се појавио први том Рјечника остаје да нагађамо и да се надамо да се академик Остојић благовремено извукао из ове нечасне работе! Уколико је црногоријанство фалсификовало овај документ, онда нека се о томе побрину истражитељи, а после тога и професору Петровићу и нама остаје - јавно извињење! 
се у основу речника уграђују редакторске бесмислице, не треба ни очекивати да такав речник може бити ишта друго до бесмислен (2. „грађа рјечника мора поред лексичког усменог и народног говора обухватити комплетан материјал писаног и умјетничког језичког стварања“ - ?!). Томе свему треба додати и још покоју недомишљеност, овде издвајам двије које се директно - боду! Прва је: „У рјечник треба да уђу, поред народних ријечи, и све оне које су се одомаћиле у књижевном језику од Вука на овамо“, а друга: „рјечник мора првенствено да буде рјечник савременог језика нове епохе“. Та два „основна концепцијска начела“ никако се не могу „помирити“, јер Вукови почеци не спадају „у савремени језик нове епохе“. И кад је већ о томе ријеч, није јасно зашто се овдје уопште помиње Вук ако се зна да се он бавио српским језиком и да је он у Црну Гору први пут дошао 1835. године (тј. пуних 20 година после почетка бављења пословима у које се упустио), а дотле о њој није знао ништа и мислио да се она налази - у Херцеговини! С друге стране, акад. Остојић досад се бавио српским језиком и није јасно кад се, и гдје (ако није код Војислава Никчевића и Новака Килибарде), специјализовао тај „црногорски“. Осим свега, Остојић је предложио и чланове „Програмског савјета за Рјечник црногорског народног и књижевног језика“, по истом обрасцу по коме се то чини, рецимо, за „Параду поноса“ или за Годишњу изложбу паса и у њему су се нашли књижевници, историчари књижевности, културолози, публицисти (никуд без Олге Перовић и Рајка Церовића!), а сам се истакао као предводник „лингвистичких аргата“, за које се не зна је ли ико икад од њих уобличио макар једну лексикографску одредницу.

Имајући на уму све поменуте појединости, треба предложити Академији и њиховим лингвистичким мајсторима да забораве оне следеће томове Речника (а планирали су их, вели академик Брано, још четири). јер 
су и овим једним довољно осрамотили и лингвистику и Црну Гору, а Академији, као и неким њеним академицима, то се више не може ни познати“.

Убојитост оцене професора Драгољуба Петровића, требало би, надамо се, да опомене оно мало лигвистичке младежи у Црној Гори да добро размисле у које се труло политичко коло хватају, да их, српски речено, „не пита старост шта им учиње младост“!

\section{Прилог 1. ДИЈАЛЕКАТСКИ РЕЧНИЦИ}

ГЛ(ИГОРИЈЕ) ЕЛЕЗОВИЋ, Речник косовско-мейохискоі gијалекйа I, СДЗб IV, Београд 1932, 1-477; II, СДЗб VI, Београд 1935, 1-587). Око 15.000 одредница. Акцентоване одреднице и ликови одредница у примерима.

СРЂАН МУСИЋ, Романизми у северозайаgној Боки Койорској, Филолошки факултет Београд, 1972, 1-274. Студија + речник. 2.260 одредница.

ВЕСНА ЛИПОВАЦ РАДУЛОВИЋ, Романизми у Црној Гори - jyīoистиочни gио Боке Койорске, Цетиње-Титоград 1981, 1-391. Око 5.000 одредница. Одреднице и примери акцентовани.

БРАНА МИТРОВИЋ, Речник тесковачкоі іовора, Лесковац $1984,1-386$. Одреднице и примери акцентовани. Око 10.000 одредница.

НИКОЛА ЖИВКОВИЋ, Речник ӣиройской іовора, Пирот 1987, 1-188. Одреднице и примјери акцентовани. Око 6.000 одредница.

МИЛЕ ТОМИЋ, Речник раяимскоі̄ іовора - (дијаспора, Румунија), СДЗб XXXV, Београд 1989, 1-174. Око 13.000 одредница. Одреднице и примери акцентовани.

РАДА СТИЈОВИЋ, Из лексике Васојевића, СДЗб XXXVI, Београд 1990, 119-380. Око 4.500 одредница. Одреднице и примери акцентовани.

М. ПЕИЋ - Г. БАЧЛИЈА, Речник бачких Буневаца, Матица српска, Нови Сад 1990, 1- 445. Око 17.000 одредница. Одреднице и примери акцентовани. 
МИЛИЈА СТАНИЋ, Ускочки речник I-II, Научна књига, Београд 1990, 1991). Око 34.000 одредница. Одреднице и примери акцентовани. ЈАКША ДИНИЋ, Речник ичимочкоі іовора (I - СДЗб XXXIV, 1988, 7-335 - 7.000 одредница, II - СДЗб XXXVI, 1990, 381-422 - 800 одредница, III - СДЗб XXXVIII, 1992, 379-596 - 3.000 одредница. Свега 10.800 одредница). Одреднице и примери акцентовани.

ЈАКША ДИНИЋ, Тимочки gијалекайски речник, Монографије 4, Институт за српски језик САНУ, Београд 2008, XXX+1921. Ново и допуњено издање Речника тимочког говора. Укупно „24.275 лексичких јединица са око педесет хиљада значења" (стр.XXV).

МИОДРАГ МАРКОВИЋ, Речник ирноречкоі їовора I - СДЗб XXXII, Београд 1986, 243-500; II - СДЗб XXXIX, Београд 1993, 149-398. Одреднице и примери акцентовани. Око 8.000 одредница.

МИЛОШ ВУЈИЧИЋ, Речник іовора Прошћења коg Мојковиа, ЦАНУ, Подгорица 1995, 1-141. Око 4.000 одредница. Одреднице и примери акцентовани.

Д(РАГОСЛАВ) М(АНИЋ) ФОРСКИ, Лужнички речник, Бабушница 1997, 1-86. Овај речник је «силом материјалних прилика и захтевом издавача скарћена верзија ширег рукописа речника народног говора у Лужници» (Илић 2005, 39). Одреднице акцентоване.

ДРАГО ЋУПИЋ и ЖЕЉКО ЋУПИЋ, Речник іовора Заїарача ( СДЗб XLIV, Београд 1997, 1-615). Око 10.000 одредница. Одреднице и примери акцентовани.

ВЕСНА ЛИПОВАЦ РАДУЛОВИЋ, Романизми у Буgви $u$ Пашитровићима, МБМ, Нови Сад 1997, 1-326). Око 4.000 одредница.

МОМЧИЛО ЗЛАТАНОВИЋ, Речник іовора јужне Србије, Врање 1998, 1- 491. Око 9.000 одредница. Одреднице и примери акцентовани.

ВУК БОРИЧИЋ ТИВРАНСКИ, Рјечник васојевићкоі іовора, Просвета, Београд 2002, 1-372. Око 12000 ријечи. Одреднице акцентоване и дате са граматичким одређењем, али без примера. 
МИХАИЛО БОЈАНИЋ И РАСТИСЛАВА ТРИВУНАЦ, Рјечник яубровачкоі іовора, СДЗб XLIX, Београд 2002, 1-458. Одреднице и примери акцентовани.

СВЕТОЗАР ГАГОВИЋ, Из лексике Пиве (Село Безује), СДЗб LI, Београд 2004, 1-312. Око 7.000 акцентованих одредница.

ВЛАСТИМИР ЈОВАНОВИЋ, Речник [іовора]села Каменице коg Ниша, СДЗб LI, Београд 2004, 313-688. Речник садржи 12.000 речи. Одреднице и примери акцентовани.

СТЕВО ДАЛМАЦИЈА, Рјечник іовора Пойкозарја, Глас српски/Графика, Бања Лука 2004, 1-363. Око 8.500 одредница. Одреднице и примери акцентовани.

РАДМИЛА ЖУГИЋ, Речник їовора јабланичкой краја, СДЗб LII, Београд 2005, 1-470. Око 9.000 одредница. Одреднице и примери су акцентовани.

ЈОВАН К. КОПРИВИЦА, Речник іовора Бағьана, Грахова и Ойуйних Руgина, ЦАНУ, Подгорица 2006, 1-224. Око 4.000 ријечи

АНЂЕЛКА ЛАЗИЋ, Грађа за речник іовора Мачве, Културни центар, Шабац 2008, 1-387. Иако, како наводи у уводу, „без претензија да уради научну монографију“, ауторка је дала око 5.300 акцентованих одредница, које прате акцентовани примери.

б) Збирке ријечи - регистри уз дијалекатске монографије. Избор: Александар Белић, Дијалектии истиочне и јужне Србије (СДЗб I, 1905, 1-715). Реїисӣар речи има 39 тростубачних страна, са око 5.500 ријечи.

Бранко Милетић, Црмнички іовор (СДЗб IX, 1940, 209-663). Регистар - стр. 621-651, 31 стр. тростубачно. Обухваћено око 5.000 ријечи и суфикса.

Јован Вуковић, Акценати іовора Пиве и Дробюака (СДЗб Х, 1940, 185-417). Речник обухвата 29 двостубачних страна. Око 420 одредница.

Павле Ивић, О іовору Галийольких Срба (СДЗБ ХІІ, 1957, 1-520). Регистар обухвата 21 тростубачну страну. Око 3.000 ријечи. Митар Пешикан, Сйароирноїорски, среgнокайунски и тешански іовори (СДЗб XV, 1965, 1-294). Око 8.000 акцентованих ријечи, са основним граматичким подацима, каткада и значењима. 
Д. Ћупић, Говор Бјелойавлића (СДЗб ХХІІІ, 1977, 1-226). Обрађено 307 турцизама и 138 романизама, са објашњењима значења.

П. Ивић, Ж. Бошњаковић, Г. Драгин, Банайски іовори шумаgијско-војвођанскої яијалекиеа II (СДЗб XLIII, 1997, 1-586). Реіистиар речи 537-568, близу 1.000 ријечи.

У новосадским Прилозима проучавању језика објављено је више збирки ријечи из народних говора.

в) Дијалектолошки терминолошки речници:

В. Михајловић - Г. Вуковић, Срйскохрваичска лексика рибар$c \bar{u} в а$ ( Институт за лингвистику у Новом Саду, 1977, 1-457 + 61 стр. фотогр. и карата). Одреднице акцентоване.

Стево Ћосовић, Ловачки речник (Сарајево, 1981, 1-158). Око 3.000 одредница, узетих из литературе и дијалеката.

Џевад Јахић, Ловачка тексика и фразеолоіија у роїаичиком крају (СДЗб ХХІХ, 1983, 339-403). Обухваћено око 700 акцентованих одредница.

Жарко Бошњаковић, Пастиирска иереминолоіија Срема (ФФ Нови Сад, 1985, 1-174). Студија 1-89, 21 карта на стр. 90-100 + речник (стр. 101-158). Нема података о броју одредница. Одреднице акцентоване.

Гордана Вуковић, Терминолоіија куће и йокућстива у Војвоgини (ФФ Нови Сад, 1988, 1-508). 120 карата и 30 скица. Речник 113-245. Акцентовано.

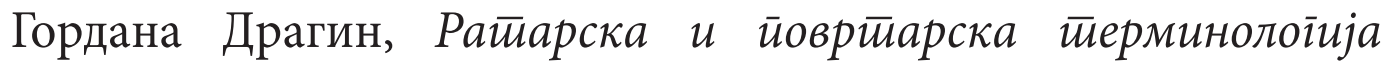
Шајкашке ( СДЗб XXXVII, 1991, 621-708, са 12 карата). Студија 621-664, речник 665-694.

Радомир Ракић, Терминолоіија сроgсиива у Срба, Одељење за етнологију Филозофског факултета у Београду, Београд, 1991.

Гроздана Комадинић, Ткачка иеерминолоіија Драїачева (Научна књига - Београд, 1993).

Софија Ракић-Милојковић, Пасииирска иеерминолоіија Кривовирскої Тимока (СДЗб XXXIX, 1993, 11-148). Студија и текстови 11-99, речник 100-140.

Марија Шпис-Ћулум, Фийонимија јуїозайаgне Бачке - коровска фллора (СДЗб XLI, 1995, 397 - 490). Студија 397-436, речник 437-483. 
Прилог 2. Речник САНУ

СР ПСКА АКААЕМИЈА НАУКА

\section{Р ЕЧ Н И К}

\section{СРПСКОХРВАТСКОГ КНИभЕВНОГ \\ I \\ НАРОАНОГ ЈЕЗИКА}

КњИГА I

A-Боїоуу 
a (A) с непром. 1. фон. а. самогласник који се изговара с највећим ойвором усий, ӥри нормалном иоложсају језика и усана: дуго , наглашено б. иррво слово ћириличе (некад звано аз) којим се обележсава йај глас.

2. (изговара се a) ӥри набрајању, навођењу $u$ cл., y значењу: йрви, -a,-o. - Одељак Б требало би спојити са одељком А, јер углавном садржи исто (Ред.). У чл. 5 тачке а Закона (И.) 3. скраћениуа за: ар (a), алт (A), ампер (A) др.

$\mathbf{a}^{1}$ муз. основни йон йо коме се одређује висина свих осйалих йонова; иесиии йон Це-дур скале; син. ла.

$\mathbf{a}^{2}$ (a) предл. (фр. à) трг. варв. ذисйрибуйивно, $y$ значеву: йо. - Пет комада оловака а 10 динара (Ред.).

$\mathbf{a}^{3}$ св. 1. суйройна а. за исйичање нечег суйройног ономе шийо би се очекивало йрема реченом y йрейходној реченици (понекад појачано са оно); исп. али ${ }^{1}$ (1a), ама (1a). - Друмови ће пожељет'

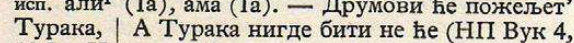
136). Новци кад одлазе имају сто ногу, а кад
13. долазе само двије (НПосл Вук). Два брата у гори брала су дрва, па огладњела а ништа собом не донијела за ручак (НПр Врч. 3,133 ). Чекамо видјело, а оно, ето мрак!; свјетлост, а оно ходимо по тами (Дан. Ђ. 12, 558). То [je] мучна ствар једном човеку из друге кнежине у туђој кнежини кнезовати, „а кад баш хоћете за кнеза Јоку из Рабаса, онда ето вам“ (Нен. М. 2, 36). Ти бајаги кмет, па засео ту у механи, a није ти ни у уво што се овамо поштеним људма гради штета (Глиш. 1, 11). Ја гајио и хранио... а они га лепо за руку па хајд' у војнике (Весел. $18,93)$. Не излијечисте никога, а јошт вам се в ерује (Јубб. 1, 27). б. за исииичање неког ограничавања йрейходног исказа: йа ийак, йрийом.Ко је Србин и Српскога рода, | ...А не дош’о на бој на Косово, | Од руке му ништа не родило (НП Вук 2, 301). в. за означавање различносиии међу двема исйовременим радњама или найоредним особинама: док, међуйим. - Мачки је до игре а мишу до плача (НПосл Вук). Једна гобела у као а друга из кала (НПр Вук, 196). У дну перје сребром заливено, А по среди златом преплетено (НП Вук 2, 302). Друго сте ви, а друго је она (Мат. 6, 13). г. (са свезом да и да не) за искључивање онога иито би се оче кивало иррема значењу иррейходне речениче (обично уз одречну реченииу). - Ти си башта, по којој и се путик до века шетао, а да не осети вреле капи тешкога умора (Јакш. Ђ. 3, 1). Све то расте... а да човјек и не осјети (Новић, ОС $1864,180)$. Она је смјела радити све се није усудио нитко приговорити (Јив. 1,44 ). Ниједна велика идеја није могла победити, а да није била скупо плаћена (Павл. Д. 1, 32). Пуцањ се разлеже по планини, а Pеџren се скљока мртав на земљу, $a$ да писну (Аврамовић С., БК 1896, 1322). д. $y$ йрuйоведануy, за исӣичање истиовременог, обично изненадног збивања, честио у корелачији с временским свезицама и йрилозима (кашто појачано са $\bar{u} о$ ); исп. али ${ }^{1}$ (1в). - Кад тамо а код оваца нема чобана (НПр Вук, 90). Док су они још то говорили, а то се помоле кола и коњи (И., 2). Нађе царицу а она седи сама (И., 27). Истом Грујо сједе за трпезу, А

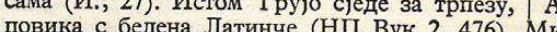
руку а вук вук, а вук на врата (НПосл Вук). Усни фараон, а он стоји на једној ријеци (Дан. Ђ. 12, 34). Дигнем се ја те вратницама. Кад а тамо стоји Пера Игњатов (Весел. 8, 93). Тек се бејаше расвануло, а пред Чолак-Антину кућу стадоше господска кола (Тод. П. 1, 245). Таман он rope а духне јак ветар (НПр Гавр. А., 99). ђ. (рейко) за означавање делимичне суйройносиии иррема ирреихходној одречној реченичи, за суйройсйављане једно йоји:

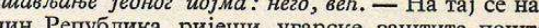

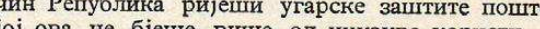
јо) ова не біс рије вии користи, од очите штете (Војн. Л. 1, 21). Ово правило... не говори овдје о законитим женама, $a$ о „сожителствующихъ", а под тим именем разумјевале су се жене... које су живиле у кућама не ожеьених људи (Милаш 2, 18).

2. сасйавна а. за исииицане истиовремене радње или найоредне особине ӥрема йрейходној ре-

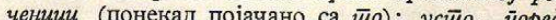

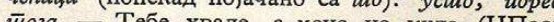
иога. - Тебе хвале, а мене не куде (НПосл Вук). Устави се на истоку сунце, | А и сјајан мјесец на западу (НП Вук 3,64 ). Ох да ми је вјенчати ђевојку да је бијела као снијег, а румена као крв (НПр Вук, 116). У њима да имамо добру узданицу, а такођер и они у нас (Вук 10 122). Сима је Ђаво да мртва уста насмеје!. Ради а прича, па ови попадаше за њим (Весел. 14, 304). Био је леп дан ране јесени, а субота (И, 194) . Вјетр риче и урла тео тивл а глатна звијер (Hев, СКГл 25, 403). Бинови имaју краk а дебље рогове, но краве и волови (Гавр. С. 


\section{Прилог 3. Рјечник ЦАНУ}

ЦРНОГОРСКА АКАДЕМИЈА НАУКА И УМЈЕТНОСТИ

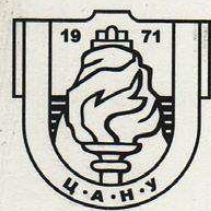

ИНСТИТУТ ЗА ЈЕЗИК И КҢИЖЕВНОСТ

„ПЕТАР II ПЕТРОВИЋ ЊЕГОШ”

Рјечници

Књига 8/I

\section{РЈЕЧНИК}

\section{ЦРНОГОРСКОГ НАРОДНОГ}

И КЊИЖЕВНОГ ЈЕЗИКА

I

A-B

Реgакција

Јелена Башановић-Чечовић

Рајка Глушица

Данијела Радојевић

I

Сања Шубарић 
a (A) 1. фон. а. ниски самоїласник среgнеї реgа. б. слово којим се обиљежава ииај самоїласник. в. иррво ӣо реgу слово ћирилице или лайинице. 2. скраћеница за ар

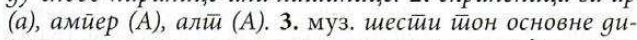
јатионске скале; основни йон йо којем се оgређује висина остиалих йонова.

- А-категорија 1. ознака за најболе или йрво йо реgу међу сйварима истие врсйе. 2. саобр. кайеїорија возила која о ухвайа мотиоиикле са бочном йриколицом или без не; А-класа ознака за најболье или иррво йо реgу ме-

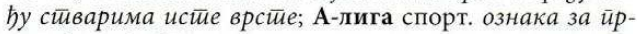
ву лиїу у сйорӣ̄y.

口е рећи ни не рећи нишйа, не йроіоворитии нијеgну ријеч; од до ші оg йочейка gо краја.

а везн. 1. суйротини: а. за везиване независних реченииа у сложеној. - На првој је години студија, а сви су већ запазили његов изразит дар. (Глуш., Шев. I) - ... ја сам се новинарством мало бавио, а никад нијесам могао да саставим нешто подношљиво о теми коју ми други одреде ... (Зог. IX) $\delta$. за везиване ријечи које сйоје у оgносу йраве суйройносӣи: сйар, а наиван. 2. сасииавни: а. $3 а$ везиваюе независних реченица у сложеној: $и$. - Видјели смо колико та народ трпи, а поштење жели ... (Поп. Миљ. М. II) - То је данас формалитет а ништа друго. (Љуб. IV) б. за везиване ријечи које сииоје у найореgном оgносу: иианак а висок. 3. растиавни, за везиване реченичних gјелов с суйройної значеюа између којих йреба бираиии: или. - А му дао, а не дао - он опет нема. (Стиј. II) - Поша а ти а он, мене исто. (Баш.-Чеч. I) - Узео га а ја а ти, свеједно је. (Ћуп. Д., Ћуп. Ж. І) 4. (кад је наглашено: ä) нар. временски: каg; чим, иеек. - А они дођу, ми ћемо кренут. (Рист. I) - Доћи ћу а могнем. (Стан. III)

а (различито наглашено) узв. а. ири чуђењу, gивльену. А што му би! (Баш.-Чеч. I) - А вала је поган до зла бога ... (Рист. I) - А, браво ви га! (Стан. III) б. ӥри неіоgоваюу, кайеїоричком оgбијаюу. - А мора се прекидат та лудорија! (Баш.-Чеч. I) - А нећу га ја горе кретат ни у помамилу! (Рист. I) - A, Baco, потроши ли ти оне паре? (Стиј. II) в. нар. за йоgстииианье, оgобраване: хајge. - А, ђецо моја, а, соколови моји! (Баш.-Чеч. I) - A, јуначе, а соколе - пождени! (Стиј. II)

а- /грч./ иррефикс који означава неіацију, немане и оясустиво оноїа шито је означено основном ријечју: асиме-

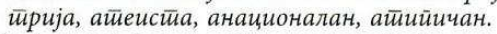

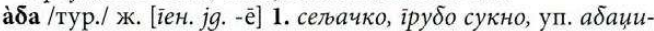
ja (1). - Бијаше Була изаткала велику трубњу абе, оног домаћег сукна. (Ћок. I) - ... поп капама коіе им се ни- ба аба, од терзије скројена - за војнике ... (Сијар. III) 2. (обично у мн.) изночено, йоиијейано оgијело, уп. ака. У теби богови буде снагу и вољу када се, усуканих мишића, избраздана лица, у дроњцима и абама, мучиш да истераш камен из камена ... (Ђур. Д. II-1) - Необријан и неошишан, сав у траљама и абама ... он је заборавио све и жалио ливаду Раму. (Ђур. Д. II-1)

а̀ба̄д/итал./ м. [їен. jg. аба́да] нар. иажна, важносй, значај. - Не даје му абада више него да није жив. (Лип.-Радул. I) - Не дајем ја томе никакав абад. (Лип.-Радул. I)

аба̀дати несври. [ӣрез. -а̄м, -ајӯ/абада́jȳ, ӣpur. cag. абàдајӯћи] нар. йрияавайи значај, марийи, бринуйи. - Не абада га она као да није жив. (Лип.-Радул. I) - Купили су му скупу кашету, а док је био жив, нијесу га абадали. (Лип.-Радул. I) - Не абада она њега ни за зеру! (Шоћ I) аба̀жӯр /фр./ м. [іен. jg. абажу́ра, инстир. jg. абажу́ром] заийийа на ламӣи која заклана свјетилости и брани очи og свјеитлостии. - А до завјесе на високом ногару лампа с широким абажуром. (Копр. Д. II) - Свјетлосни зраци извиру одасвуда ... изнад експоната извијени лукови са металним абажурима који бацају усмјерено свјетло ... (Пер. Слав. I)

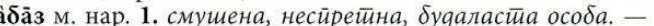
Удала се за нака абаза, куку јој у памет. (Гаг. I) - Срете ме онај Петров абаз па поче да булазни. (Ђок. I) - Какав је оно абаз, гром га убио! (Стиј. II) 2. gомаћа живойина. - Причува те абазе да ти не поарау туђе. (Ћуп. Д, Ћуп. Ж. I) - Он је само за чување абаза, низашто друго. (Ћуп. Д., Ћуп. Ж. I)

ӓбаза̄ст, -а, -о [ogp. ӓбазастй] нар. који је несйретиан, несналажљив; йриїлуй. - Поштен је и истинит, но, вала, помало и абазаст. (Стиј. II) - Откуд би оно абазасто дијете од онако финија родитеља. (Стиј. II)

аба̀йн /итал./ м. [їен. jg. абаи́на] нар. ойвор на крову који gаје свјетилости ӣойкровљу и који служи као излаз. - Морам зват мештра да ми поправи абаин. (Лип.-Радул. I) - Кроз абаин се попео на интећ да претресе и стави тигле. (Лип.-Радул. І)

абандоेнати /итал./ сври. [ӥрез. -ӓм, -ајӯ/абандона́jȳ] нар. найустии $\bar{u} u, ~ о с \bar{u} а в и \bar{u} и$. - Пожали Његоша, поплачи, ама и своју муку не абандонај. (Вук. Ч. III)

абанду̀нати и абанду̀њати сври. [йрез. -а̄м, -ајӯ/aбандуна́jȳ и -ãjy/абандуња́jȳ] нар. в. абанgонайu. - Абандунала је она школу и аларгала се од краја. (Лип.-Радул. I) - Абандуњао је, иако је ш њом одио три године. (Лип.-Радул. I)

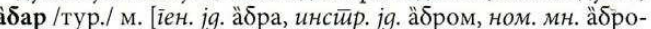
виl нар. в. абер. - Милуша аброве проноси покле по- 


\section{Литература:}

Грошел 2003: B. Gröschel, Postjugoslavische amtspachenregelungen, Српски језик VIII, Београд: Научно друштво за неговање и проучавање српског језика

Елезовић 1932: Г. Елезовић, Преgїовор Речнику косовско-метиохискоі gијалекйа, том I, Београд: Институт за српски језик.

Згуста 1991: L. Zgusta, Priručnik leksikografije, Sarajevo: Svjetlost Ивић 1991: П. Ивић, О Вуку Карачићу, О Вуковом Срйском рјечнику из 1818. іолине, Целокупна дела Павла Ивића, књ. IV: Сремски Карловци / Нови Сад: Издавачка књижарница Зорана Стојановића

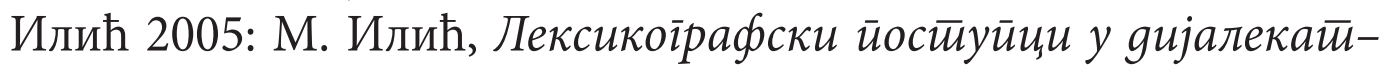
ским речницима јуіоостиочне Србије, Ниш: Просвета

Ковачевић / Шћепановић 2001: М. Ковачевић / М. Шћепано-

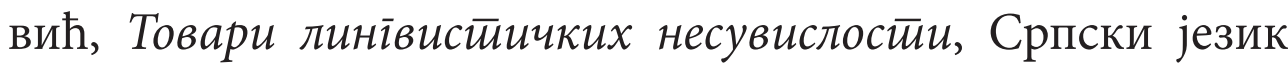
VI, Београд: Научно друштво за неговање и проучавање српског језика

Петровић 1982: Д. Петровић, Проблеми и изілеgи срйскохрвайске gијалекайске лексикоірафије, Лексикологија и лексикографија, зборник радова: Београд / Нови Сад: Институт за српскохрватски језик

Петровић 1990: Д. Петровић, Преgїовор Речнику бачких Буневаца, Нови Сад / Суботица: Матица српска

Петровић 2000: Д. Петровић, Преgїовор Речнику срӣских іовора y Војвоgини, Нови Сад: Матица српска

Петровић 2017: Д. Петровић, Моgерна Црна Гора се канgugује за кайоличене (иниетерју), Српске новине 91/VII, Подгорица: НВО Друштво за равноправност и толеранцију

Риђановић 2003: M. Ridjanović, Totalni promašaj, Sarajevo:

Ћорић 2008: Б. Ћорић, Творба именища у срском језику, Београд: Друштво за српски језик и књижевност Србије Ћупић 2000: Д. Ћупић, Дијалекайски (реічонални) речнищи срйскоїа језика, Српски језик 5/1-2, Београд: 703-711.

Шћепановић 2017: М. Шћепановић, Пойурена нам је још јеgна шарена лажа (редакцијски наслов), Београд: Печат, 07.04.2017. 
Mihailo M. Šćepanović

University of Belgrade

Faculty of Philology

\section{THE SERBIAN LANGUAGE AS MONTENEGRIN}

(On the Example of the Absurd Compilation of the Dictionary of the Montenegrin Vernacular and Standard Language and the Serbian-Speaking Area Now)

\section{Summary}

The paper discusses the current trends in the development of Serbian dialectal lexicography, reviews the methodological assumptions in the compilation of dialectal dictionaries (from the selection of the entry and the clarification of its interrelation with the adjacent speeches and speech types on the one hand, and the state in the standard language on the other hand). The paper also includes a bibliography of the lexicographical results in the field so far, as well as an overview of the methodological issues following this type of linguistic research. Based on such a model and on the overview of the entire Serbian-speaking area and current linguopolitical reshaping of that area, and the renaming of the Serbian language, the publication of the first volume of the Dictionary of the Montenegrin Vernacular and Standard Language is analysed as an amateur approach to lexicographic material.

Key words: dialectal lexicography, lexicographic technique, dialectal dictionary, dialexeme, urban dialect, reshaping of language, Serbian languages. 